\title{
NOTES
}

\section{UNRECORDED COPIES OF MIDDLE ENGLISH VERSE AND PROSE IN DUBLIN, TRINITY COLLEGE, MS 352}

Dublin, Trinity College, MS 352 is a commonplace book written in England in the first half of the sixteenth century. Its 29I paper leaves measure $\mathrm{I} 48 \mathrm{~mm}$ $\times 89 \mathrm{~mm}$ making a small, fat volume, convenient for holding in the hand. Its Latin and English contents comprise a series of quotations and extracts from the Bible, the works of the Church Fathers, late medieval religious texts, and contemporary theological writings. There is as yet no catalogue of the medieval English manuscripts in the Trinity College collection, and Marvin Colker's catalogue of the medieval Latin manuscripts gives only a brief summary of this volume's contents. ${ }^{1}$ The various pieces in English in MS 352, which include some post-I5Oo copies of Middle English texts, have therefore mostly gone unnoticed.

The Middle English consists of extracts from Walter Hilton's Scale of Perfection and from Dives and Pauper, and some memento mori verses. This cluster of material is copied on fols $106^{\mathrm{r}}-\mathrm{I} 2 \mathrm{I}^{\mathrm{r}}$.

The extracts from Walter Hilton's Scale of Perfection are introduced by the heading 'Scala perfectionis' (fol. Io6 ${ }^{\mathrm{r}}$ ). The extracts, not all of which I have been able to identify, take up fols $106^{\mathrm{r}}-\mathrm{II}^{\mathrm{v}}$, and include material from Book II chapter 22 on remedies against temptations. One quotation from that chapter ('What am I? I am nought, I haue nought, I covett nought, but only the love of oure sweete lorde and savyour christ Jesu') is marked as 'a notable sayng' (fol. Io $8^{\text {r) }}{ }^{2}$

The material from the Scale is followed by some selections from Dives and Pauper, the long fifteenth-century didactic exposition of the Decalogue. The extracts are from the section on the sixth commandment, and the source is again acknowledged through a heading: 'Dives et pauper' (fol. II $7^{\mathrm{r}}$ ). Another heading specifies that this material comprises 'Certen remedies ageinst the temptation of lechery', introducing advice on abstinence and bodily occupation taken from chapter $14 .^{3}$ This is followed by a number of verses, almost all of which occur in chapter $15 .{ }^{4}$ The verses are given the heading 'Certen verses', and copied continuously on fol. $\mathrm{I}^{2} \mathrm{O}^{\mathrm{r}-\mathrm{v}}$. In spite of this layout it is clear from variations in form, line-length, and speaking voice that various separate items have been run together here, three of them derived from chapter Is of Dives and Pauper. Only four of the lines, the opening and closing couplets, may not be attributed to 
this source (and only the final couplet is not attributable at all). Since these lines frame the rest of the extracts, and use a didactic form of address that is absent from the other verses, this may represent some attempt to create a new piece of devotional instructional verse by the stitching together of borrowed materials.

The twenty-eight lines of verse are presented here as they are copied on fol. $\mathrm{I}^{2} \mathrm{O}^{\mathrm{r}-\mathrm{v}}$ in MS 352, with references given to the relevant entries in $A$ New Index of Middle English Verse (NIMEV). ${ }^{5}$ In transcriptions from the manuscript abbreviations have been silently expanded and modern punctuation added.

Thinke on Christ and haue him in mynde, that vnto thee was soo kinde. ${ }^{6}$

Behold my woundes and haue them in thy thought:

for all the goodes that be thyne, with my bloud I haue them bought.?

While I haue his bloud in mynde,

that was to mee soo goode and kynde,

I shall neuer other take,

but him that died for my sake. ${ }^{8}$

When I thinke on Christes bloud, that he shed vpon the Roode,

I lett teares smarte;

What man may be soo vnkinde,

that Christes bloud hathe in minde,

entierly in his herte. [fol. $\mathrm{I}^{2} \mathrm{O}^{\mathrm{v}}$ ]

Sweete Jesu Christ what was thy gylte,

that thow thus for mee arte spilte,

floure of all goodnes;

I am a theefe, and thow dieste,

I am giltie, and thow abieste,

all my wickednes.

Why gavest thow soo muche for thyne,

What wynnest thow with thyne hard pyne,

Riche in blisse aboue;

Love thyne harte soo deepe hathe sought,

that payne of deathe leuethe the nought,

to wynne mans love. ${ }^{9}$

Thanke Christ for his endlesse charitie,

that he would suffer soo muche for thee.

The narrative voice varies in these lines from that of an adviser who tells the listener to 'Thinke on Christ', to Christ himself ('Behold my woundes'), and then the individual Christian ('While I haue his bloud in mynde'), before returning finally to the adviser again. There is no attempt to smooth out these abrupt changes in address. But the substitution of the gender-neutral 'other' in line 7 where the occasion of the exemplary tale of the bloody shirt in Dives and Pauper had made 'husbond' an appropriate term (and the version edited 
by Brown cited above has 'lover'), is more suited to the present context of the commonplace book, and may have been a deliberate change.

The remainder of fol. $\mathrm{I}^{2} \mathrm{O}^{\mathrm{v}}$ was originally left blank. One further piece of Middle English verse is copied on fol. $\mathrm{I}^{\mathrm{r}} \mathrm{r}^{\mathrm{r}}$ :

Loke man before thee, howe thy life wastethe,

Loke man behinde thee, howe thy deathe hastethe,

Loke man on thy right side, howe synne thee defilethe,

Loke man on thy lefte syde, howe the devill thee begylethe,

Loke man benethe thee, is payne without reste,

Loke man aboue thee, is ioye that euer shall last.

NIMEV cites four other witnesses for this set of three couplets, including an instance where they appeared as a tomb epitaph. ${ }^{10}$ None of these versions exactly matches the form given in MS 352 which most closely resembles that in Cambridge, Magdalene College, MS I3, 'Looke before the how thi lyfe wastyth'. ${ }^{11}$ Of the other copies it might be noted that in London, British Library, Harley MS 1706 these verses occur on fol. $154^{\mathrm{r}-\mathrm{v}}$ before the text Contemplations of the Dread and Love of God and not (as stated in the British Library's online catalogue description and other sources) on fol. $204^{r-v}$ after the conclusion of that text.

The last of these three couplets occurs alone, in reversed form, in Oxford, Bodleian Library, MS Ashmole 750, a miscellany of Latin and English texts that contains amongst other religious items a series of extracts from Dives and Pauper. ${ }^{12}$ This manuscript was copied in the second quarter of the fifteenth century, and Priscilla Barnum notes that this propensity towards selection characterized the reception of Dives and Pauper from an early stage, and that the text remained influential in the years leading up to the English Reformation. ${ }^{13}$ Printing extended the reach of its influence. Dives and Pauper was printed by Richard Pynson in I493 (STC 19212), by Wynkyn de Worde in 1496 (STC 19213), and by Thomas Berthelet in 1536 (STC 19214). In fact, by the first decade of the sixteenth century all of the texts mentioned here were available in print: de Worde printed the Scale of Perfection in 1494 (STC I4042, Part I) and the Gesta Romanorum in [?1502] (STC 21286.2); all three works had been reprinted at least once by the I530s. ${ }^{14}$ It is therefore quite possible that some of the Middle English materials in MS 352 were copied from printed sources. I have not done a full collation, but a comparison of the verses from Dives and Pauper in MS 352 with Barnum's edition shows that minor textual variations in MS 352 accord with variant readings that she lists for the BYL group of manuscripts. ${ }^{15}$ This is significant, since it has elsewhere been demonstrated that Pynson's printed edition, on which the editions by de Worde and Thomas Berthelet depended, was based on the text of B, Oxford, Bodleian Library, MS Eng. th. d. $36 .{ }^{16}$ 


\section{NOTES}

1 Marvin L. Colker, Trinity College Library, Dublin: Descriptive Catalogue of the Medieval and Renaissance Latin Manuscripts (Aldershot, I99I), I, 750f.; the entry also records some sixteenth- and seventeenth-century names and inscriptions.

2 Equivalent to Book II, lines I234f. in Walter Hilton, The Scale of Perfection, ed. Thomas H. Bestul (Kalamazoo, Mich., 2000). MS 352 is listed amongst the witnesses of the Scale in Index of Printed Middle English Prose, ed. R. E. Lewis, N. F. Blake, and A. S. G. Edwards (New York and London, 1985).

3 See Dives and Pauper, ed. Priscilla H. Barnum, EETS, os 275, 280, and 323 (Oxford, 1975, I980, and 2004), vol. I, part II, 95.

${ }^{4}$ On the occurrence of verse in this prose text see Francis J. Sheeran, 'Ten verse fragments in Dives and Pauper', Neuphilologische Mitteilungen, 76 (1975), 257-70.

5 Julia Boffey and A. S. G. Edwards, A New Index of Middle English Verse (London, 2005).

${ }^{6}$ NIMEV 3568.5 lists two instances of a similar couplet in the Gesta Romanorum.

7 NIMEV 497.55 lists eight other manuscript witnesses, all copies of Dives and Pauper; see Dives and Pauper, ed. Barnum, vol. I, part II, Ioo.

${ }^{8}$ NIMEV 4074.22 lists eight other manuscript witnesses, all copies of Dives and Pauper; see Dives and Pauper, ed. Barnum, vol. I, part II, Ioo. One further similar copy is listed under NIMEV 3569 and printed in Religious Lyrics of the XVth Century, ed. Carleton Brown (Oxford, I939), p. 328.

9 NIMEV 3967.55 lists eight other manuscript witnesses, all copies of Dives and Pauper; see Dives and Pauper, ed. Barnum, vol. I, part II, IO2.

${ }^{10}$ NIMEV I937; also listed as TM 928 by William A. Ringler, Jr, Bibliography and Index of English Verse in Manuscript I50I-I558 (London, 1992). Texts of the four versions are given by M. P. Harley, 'A reconsideration of the Middle English verses in Bodleian Library MS. Tanner 20I', Bodleian Library Record, I2 (1989), I95-20I (pp. 195-7).

${ }_{11}$ Transcribed by M. R. James, A Descriptive Catalogue of the Manuscripts in the College Library of Magdalene College, Cambridge (Cambridge, 1909), p. 26.

${ }^{12}$ NIMEV 1939.5; for the prose contents see L. M. Eldredge, Index of Middle English Prose, Handlist IX: Manuscripts Containing Middle English Prose in the Ashmole Collection, Bodleian Library, Oxford (Cambridge, 1992), pp. 22-7.

13 Dives and Pauper, ed. Barnum, II, lxxxii-lxxxiii.

${ }^{14}$ Details of the reprints are given in Index of Printed Middle English Prose, ed. R. E. Lewis, N. F. Blake, and A. S. G. Edwards (New York and London, 1985), nos 156, 255, and $\mathrm{I} 72$ respectively.

15 The sigla denote, respectively: Oxford, Bodleian Library, MS Eng. th. d.36; Yale University Library, MS Beinecke 228; Lichfield Cathedral Library, MS 35. For discussion of the manuscript relations see Dives and Pauper, ed. Barnum, II, lxxvi-lxxxiii.

16 Margery M. Morgan, 'Pynson's manuscripts of Dives and Pauper', The Library, 5th Series, 8/4 (I953), 2I7-28. 